\title{
Decreased anxiety-like behavior, reduced stress hormones, and neurosteroid supersensitivity in mice lacking protein kinase $\mathrm{C} \varepsilon$
}

\author{
Clyde W. Hodge, ${ }^{1}$ Jacob Raber, ${ }^{2}$ Thomas McMahon, ${ }^{1}$ Helen Walter, ${ }^{1}$ \\ Ana Maria Sanchez-Perez, ${ }^{1}$ M. Foster Olive, ${ }^{1}$ Kristin Mehmert, ${ }^{1}$ A. Leslie Morrow, ${ }^{3}$ \\ and Robert O. Messing ${ }^{1}$
}
${ }^{1}$ Ernest Gallo Clinic and Research Center, Department of Neurology, University of California San Francisco, Emeryville, California, USA
${ }^{2}$ Gladstone Institute of Neurological Disease, University of California San Francisco, San Francisco, California, USA
${ }^{3}$ Department of Pharmacology and Department of Psychiatry, University of North Carolina, Chapel Hill, Chapel Hill,
North Carolina, USA

\begin{abstract}
Mice lacking protein kinase $\mathrm{C} \varepsilon(\mathrm{PKC} \varepsilon)$ are supersensitive to positive allosteric modulators of gamma aminobutyrate type $\mathrm{A}\left(\mathrm{GABA}_{\mathrm{A}}\right)$ receptors. Since many of these compounds are anxiolytic, we examined whether anxiety-like behavior is altered in these mice. PKC $\varepsilon$-null mice showed reduced anxietylike behavior and reduced levels of the stress hormones corticosterone and adrenocorticotrophic hormone (ACTH). This was associated with increased sensitivity to neurosteroid modulators of $\mathrm{GABA}_{\mathrm{A}}$ receptors. Treatment of $P K C \varepsilon$-null mice with the $\mathrm{GABA}_{\mathrm{A}}$ receptor antagonist bicuculline restored corticosterone levels and anxiety-like behavior to wild-type levels. These results suggest that increased $\mathrm{GABA}_{\mathrm{A}}$ receptor sensitivity to neurosteroids contributes to reduced anxiety-like behavior and stress hormone responses in PKCE-null mice. The findings also suggest $\mathrm{PKC} \varepsilon$ as a possible therapeutic target for development of anxiolytics.
\end{abstract}

J. Clin. Invest. 110:1003-1010 (2002). doi:10.1172/JCI200215903.

\section{Introduction}

Anxiety is a physiological, protective response to real or potential threats. Excessive anxiety is a feature of several affective disorders and has a lifetime prevalence as high as $25 \%$ in the United States (1). Current evidence indicates that genetic factors regulate anxiety. Human studies have detected associations between panic disorder and polymorphisms in genes for MAO-A (2), the adenosine A2a receptor (3), and cholecystokinin $(4,5)$. Physiological anxiety appears to be a polygenic trait, and recent analysis of high- and low-activity strains of mice

Received for publication May 10, 2002, and accepted in revised form July 30, 2002.

Address correspondence to: Robert O. Messing, Ernest Gallo Clinic and Research Center at UCSF, 5858 Horton Street, Suite 200, Emeryville, California 94608, USA. Phone: (510) 985-3950; Fax: (510) 985-3101; E-mail: romes@itsa.ucsf.edu.

Clyde W. Hodge and Jacob Raber contributed equally to this work. Clyde W. Hodge's present address is: Department of Psychiatry, Center for Alcohol Studies, University of North Carolina, Chapel Hill, North Carolina, USA.

Jacob Raber's present address is: Department of Behavioral Neuroscience and Department of Neurology, Oregon Health and Science University, Portland, Oregon, USA.

Conflict of interest: No conflict of interest has been declared. Nonstandard abbreviations used: corticotropin-releasing factor $(\mathrm{CRF})$; protein kinase $\mathrm{C}(\mathrm{PKC})$; glutamate decarboxylase (GAD); gamma aminobutyrate $(\mathrm{GABA})$, GABA type $\mathrm{A}\left(\mathrm{GABA}_{\mathrm{A}}\right)$; adrenocorticotrophic hormone (ACTH); paraformaldehyde (PFA); arginine vasopressin (AVP); paraventricular nucleus of the hypothalamus (PVN). has identified quantitative trait loci on chromosomes 1 , $4,7,12,14,15,18$, and $\mathrm{X}$ that influence anxiety-like behaviors (6). Moreover, several single gene mutations alter anxiety-like behavior in mice, including null mutations in the corticotropin-releasing factor (CRF) receptor- $1(7,8)$, the glucocorticoid receptor $(9)$, the $\alpha$ subunit of calcium/calmodulin-dependent protein kinase II (10), and protein kinase $\mathrm{C} \gamma(\mathrm{PKC} \gamma)(11)$, which all reduce anxiety-related behaviors. In contrast, null mutations in glutamate decarboxylase (GAD) 65 (12), which synthesizes gamma aminobutyrate (GABA), the GABA type $A\left(G A B A_{A}\right)$ receptor $\gamma 2$ subunit (13), CRF receptor$2(14,15)$, and the serotonin $5-\mathrm{HT}_{1 \mathrm{~A}}$ receptor $(16-18)$ increase anxiety-like behavior in mice.

Most drugs used to treat anxiety act at $\mathrm{GABA}_{\mathrm{A}}$ or serotonin receptors (19). Using PKCE-null mice, we found evidence indicating that $\mathrm{PKC} \varepsilon$ regulates the function of $\mathrm{GABA}_{\mathrm{A}}$ receptors. These mice are similar in length and weight to wild-type littermates, behave normally in their home cage, and show no compensatory changes in the abundance of other PKC isozymes in the nervous system $(20,21)$. They show reduced ethanol preference and operant self-administration of ethanol $(20,22)$ in association with heightened sensitivity to the locomotor-activating effects of ethanol and diazepam and to the hypnotic actions of pentobarbital, ethanol, and diazepam, which are positive allosteric modulators of $\mathrm{GABA}_{\mathrm{A}}$ receptors (20). This is associated with increased sensitivity to the actions of ethanol 
and flunitrazepam on $\mathrm{GABA}_{\mathrm{A}}$ receptor function in vitro. Since drugs that activate $\mathrm{GABA}_{A}$ receptors reduce anxiety, we predicted that PKCE-null mice would show reduced anxiety-like behaviors. Here we report that absence of PKCE reduces anxiety-like behaviors and stress responses by enhancing $\mathrm{GABA}_{\mathrm{A}}$ receptor function in the CNS. This involves, in part, heightened sensitivity to the positive allosteric action of endogenous neurosteroids at $\mathrm{GABA}_{\mathrm{A}}$ receptors.

\section{Methods}

Materials. (+)-Bicuculline (Sigma-Aldrich, St. Louis, Missouri, USA) was dissolved in $50 \mu \mathrm{l}$ of glacial acetic acid, diluted in saline to $\mathrm{pH} 3.0$, and administered to mice at $10 \mathrm{ml} / \mathrm{kg}$ body weight. Vehicle-treated mice received an equal volume of acidified saline. Alphaxalone was purchased from ICN Biomedicals Inc. (Aurora, Ohio, USA), and allopregnanolone, pregnanolone, CRF, and metyrapone were from SigmaAldrich. Alphaxaolone, allopregnanolone, pregnanolone, and metyrapone were prepared as $10-\mathrm{mM}$ stock solutions in DMSO. All drugs were administered by intraperitoneal injection.

Animal care. PKCe-null mice were derived by homologous recombination in J1 embryonic stem cells (21). $F_{1}$ generation hybrid $\mathrm{C} 57 \mathrm{Bl} / 6 \mathrm{~J} \times 129 \mathrm{SvJae}$ heterozygous progeny were intercrossed to generate $\mathrm{F}_{2}$ generation hybrid wild-type and PKC $\varepsilon$-null littermates for study. In early work, some studies were performed using $\mathrm{F}_{3}$ and $\mathrm{F}_{4}$ generation hybrid mice, produced by intercrossing $\mathrm{C} 57 \mathrm{Bl} / 6 \mathrm{~J} \times 129 \mathrm{SvJae}$ heterozygous mice from the previous generation. The results obtained were similar to those obtained with $\mathrm{F}_{2}$ hybrid mice and therefore were pooled with $\mathrm{F}_{2}$ hybrid data. Chimeras were also crossed with 129SvJae mice to generate inbred 129SvJae wildtype and PKCe-null littermates for some experiments. For behavioral and stress hormone studies, 10- to 12week-old mice were maintained under a 12-hour light/dark cycle (lights on at 6 a.m.) and were individually housed for 4 days prior to study. Behaviors were examined during the light phase between $10 \mathrm{a} . \mathrm{m}$. and 1 p.m. For in vitro studies of $\mathrm{GABA}_{\mathrm{A}}$ receptor function, we used group-housed male and female mice. Unless otherwise designated, we used mice of both genders for studies. The experimental mice were fed standard lab chow ad libitum. The Institutional Animal Care and Use Committees of the University of California, San Francisco and the Ernest Gallo Clinic and Research Center approved all experimental procedures.

Open-field testing. Spontaneous locomotor activity was measured in brightly lit (500 lux) chambers $(43 \times 43 \mathrm{~cm})$ as described (21). For assessment of activity in the center of the field, the chamber floor was divided post hoc into a center zone $(21 \times 21 \mathrm{~cm}$; center equidistant from all four walls of the chamber) and a periphery zone (the remaining area of the floor). Distance traveled and time spent in each area was calculated from the locomotor activity data. After each test session, the equipment was cleaned with $70 \%$ ethanol to remove animal odors.
Elevated plus maze. Mice were examined in a quiet room under normal fluorescent room light (500 lux). Two different mazes were used. The first, used in Figure 2, was elevated $60 \mathrm{~cm}$ off the floor, constructed of wood coated with gloss enamel white paint, and had two open arms $(37 \mathrm{~L} \times 8 \mathrm{~W} \mathrm{~cm})$ and two closed arms $(37 \mathrm{~L} \times 8 \mathrm{~W} \times 14 \mathrm{H} \mathrm{cm})$ extending from a common central platform $(8 \mathrm{~cm} \times 8 \mathrm{~cm})$. White tape was placed on the floor to provide traction. An observer blind to the genotype of the mouse placed it on the central platform and allowed it to wander for 10 minutes. The observer remained in the room during the test. The $x$ and $y$ coordinates of the center of the mouse were continuously monitored $(30 \mathrm{~Hz})$ in the maze using a videotracking system (Videomex-V; Columbus Instruments, Columbus, Ohio, USA). Following each session, the maze was cleaned with $70 \%$ ethanol to remove odors. Studies described in Figure 6 were performed using this maze and another maze constructed of Plexiglas (Hamilton-Kinder LLC, Poway, California, USA). This second maze consisted of two open arms $(38 \mathrm{~L} \times 5 \mathrm{~W}$ $\mathrm{cm})$ and two closed arms $(38 \mathrm{~L} \times 5 \mathrm{~W} \times 15 \mathrm{H} \mathrm{cm})$, with a central intersection $(5 \mathrm{~cm} \times 5 \mathrm{~cm})$ elevated $75 \mathrm{~cm}$ above the floor. A Plexiglas rim framed the edges of the open arms. Movement was detected by rows of 48 infrared photobeams interfaced with a computer. An observer blind to the genotype of the mouse placed it on the central platform and allowed it to wander in the maze for 10 minutes. The observer was not present in the room during this time. Results from both mazes were similar and were combined for analysis.

${ }^{36} \mathrm{Cl}$ uptake assay. Muscimol-stimulated ${ }^{36} \mathrm{Cl}$ uptake was measured in cortical microsacs as described (20). Neurosteroids were present during the 5-second incubation with muscimol and ${ }^{36} \mathrm{Cl}$.

Hormone measurements. Studies were performed between 9 and $11 \mathrm{a} . \mathrm{m}$. Brain allopregnanolone concentrations were measured in mice anesthetized with $\mathrm{CO}_{2}$ and then decapitated. The brain was rapidly removed, and the forebrain was dissected free, frozen in liquid nitrogen, and stored at $-70^{\circ} \mathrm{C}$. The concentration of allopregnanolone in the forebrain was measured by RIA (23). Plasma corticosterone and adrenocorticotrophic hormone $(\mathrm{ACTH})$ were measured before and after restraint stress. For basal levels, mice were anesthetized with $\mathrm{CO}_{2}$ and then rapidly decapitated. Blood was collected from the trunk. For studies of restraint stress, mice were placed in a plastic restrainer consisting of a smooth tube with a fenestrated stopper at the end. The tube limited the animal's ability to move about, but there was enough space for the mouse to turn around. After being restrained for 10 minutes, mice were anesthetized with $\mathrm{CO}_{2}$ and decapitated for collection of trunk blood either immediately after removal from the restrainer or 1 hour later. Hormone-stimulation tests were performed on mice individually housed for 3 days before intraperitoneal injection of either CRF (10 $\mu \mathrm{g} / \mathrm{kg})$, metyrapone $(100 \mathrm{mg} / \mathrm{kg})$, or an equivalent volume of saline. Thirty minutes after injection, mice were 


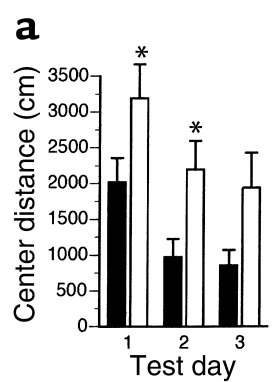

b

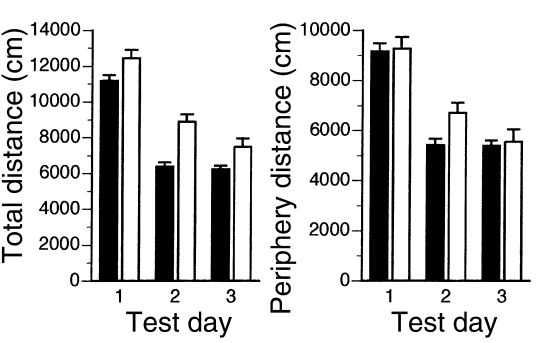

d

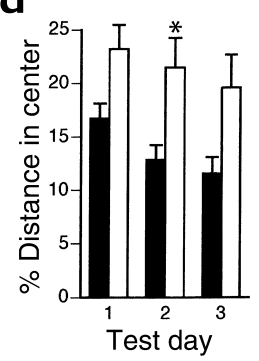

e

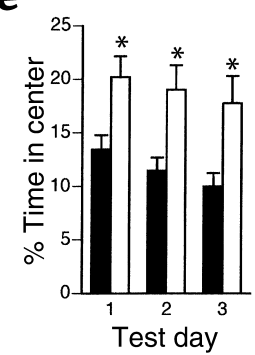

\section{Figure 1}

Open-field activity. Data are mean \pm SEM values from 19 wild-type and 20 PKC $\varepsilon$-null hybrid mice. (a) Locomotor activity in the center varied as a function of genotype $\left(F_{1,38}=5.1, P<0.05\right)$ and test day $\left(F_{2,64}=26, P<0.001\right)$ (two-way repeated measures ANOVA). ${ }^{*} P<0.05$ compared with wild-type mice on the same day (Tukey's test). Activity also varied by test day in the periphery $(\mathbf{b})\left(\mathrm{F}_{2,64}=37.2\right.$, $P<0.001)$ and total field $(c)\left(F_{2,64}=38.6, P<0.001\right)$, but not by genotype in these areas. Activity on days 2 and 3 was different from that on day 1 regardless of genotype or area (Tukey's test, $P<0.05$ ). (d) The percentage of total distance traveled in the center varied by genotype $\left(F_{1,38}=5.7, P=0.022\right)$ and test day $\left(F_{2,64}=12.7\right.$, $P<0.001)$ and was less on days 2 and 3 compared with day 1 (Tukey's test, $P<0.05)$. (e) The percentage of time spent in the center varied by genotype $\left(F_{1,38}=8.1, P=0.007\right)$ and test day $\left(F_{2,64}=5.8, P=0.005\right)$, and was less on day 3 compared with day 1 (Tukey's test $P<0.05)$. ${ }^{*} P<0.05$ compared with wild-type mice on the same day (Tukey's test).

anesthetized with $\mathrm{CO}_{2}$ and decapitated to collect trunk blood for analysis. Plasma corticosterone and ACTH were measured using ${ }^{125}$ I RIA kits from ICN Biomedicals Inc. (Costa Mesa, California, USA).

Immunohistochemistry. An affinity-purified anti-PKCE polyclonal antibody SN134 was generated in rabbits (SynPep Corp., Dublin, California, USA) against the C-terminal mouse PKCe peptide NQEEFKGFSYFGEDLMP (24). Mice were perfused with PBS, followed by $4 \%$ paraformaldehyde (PFA) in $0.1 \mathrm{M}$ phosphate buffer, $\mathrm{pH}$ 7.4. Brains were removed and postfixed overnight in 4\% PFA, equilibrated for 48 hours in 30\% sucrose in PBS at $4{ }^{\circ} \mathrm{C}$, embedded in OCT (Sakura Finetek, Torrance, California, USA), and frozen in liquid nitrogen. PKCE immunoreactivity was identified in $10-\mu \mathrm{m}$ frozen sections using SN134 $(0.4 \mu \mathrm{g} / \mathrm{ml})$ followed by detection with biotinylated anti-rabbit IgG and avidin-peroxidase (Vector Laboratories, Burlingame, California, USA).

Loss of the righting reflex. Mice were given an intraperitoneal injection of pregnanolone $(32 \mathrm{mg} / \mathrm{kg})$ and placed on their backs. The time interval between loss and return of the righting reflex was then recorded. Animals were judged to have regained the reflex when they could right themselves three times within a 30-second interval.

\section{Results}

Reduced anxiety-like behaviors in PKC-null mice. Since mice have a natural aversion to the brightly lit center of an open field, comparison of activity in the center versus the periphery of the field gives an indication of anxietyrelated behavior (25). Since three-factor ANOVA revealed no significant difference in activity as a function of gender or a gender by genotype interaction, we combined data from male and female mice. Activity did not vary by genotype in the periphery or total areas of the field (Figure 1, b and c). However, PKCE-null mice traveled more in the center than wild-type mice on days 1 and 2 (Figure 1a). Moreover, the percentages of total distance traveled and total time spent in the center were significantly greater in PKCE-null mice compared with wild-type littermates (Figure 1, $d$ and e).

We next performed an elevated plus maze test, which exploits the conflict between exploration of a novel area and aversion to open areas and height. We used inbred 129SvJae mice in addition to hybrid $\mathrm{C} 57 \mathrm{BL} / 6 \mathrm{~J} \times 129 \mathrm{SvJae}$ mice to determine if decreases in anxiety-like behavior could be observed on a different genetic background. Hybrid PKCe-null mice spent a greater percentage of time in the open arms and showed a greater percentage of entries into the open

a
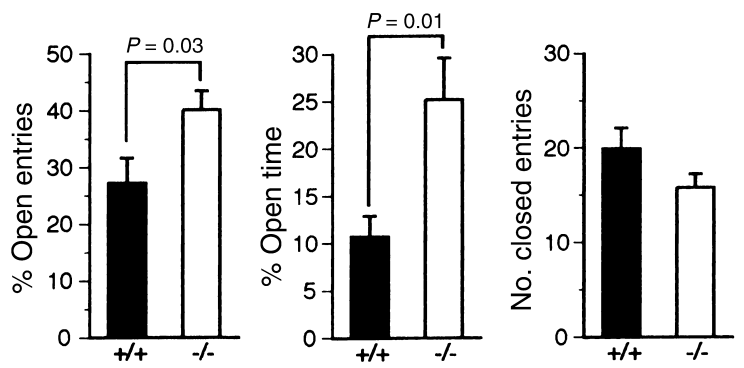

b
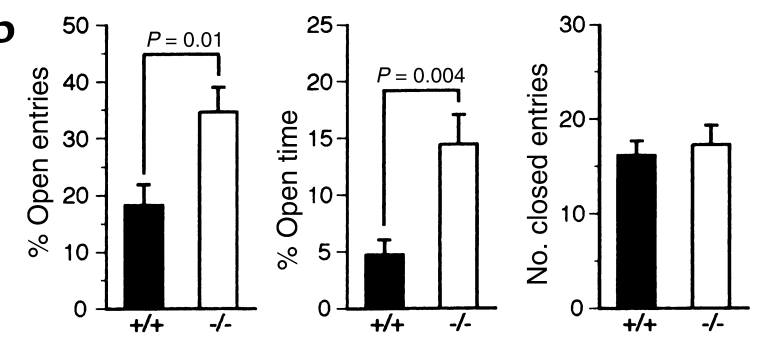

Figure 2

Elevated plus maze test. The percentage of entries into the open arms and the percentage of time spent on the open arms was greater in hybrid (a) and 129SvJae (b) PKCE-null male mice compared with wild-type male littermates. The number of entries into the closed arms was similar in both genotypes regardless of genetic background. Data are mean \pm SEM values from 12 hybrid wild-type and 12 hybrid PKC $\varepsilon$-null male mice, and 8 wild-type 129SvJae and 7 PKC $\varepsilon$-null 129SvJae male mice (two-tailed $t$ tests). 

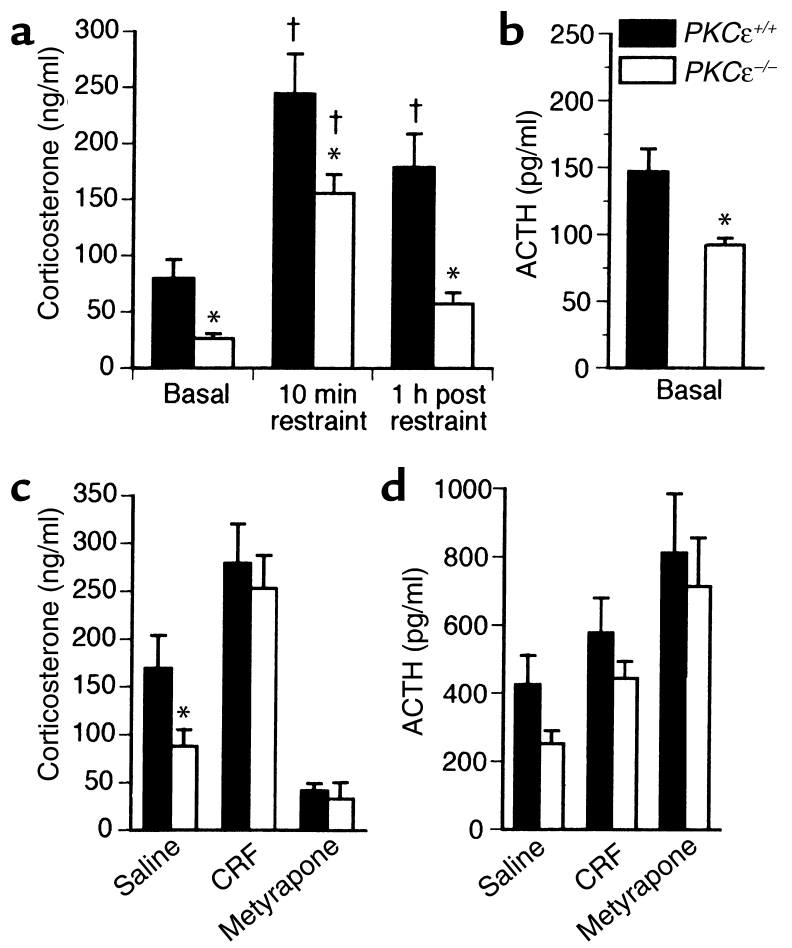

Figure 3

Stress hormone responses. (a) Mean \pm SEM corticosterone levels in hybrid male mice before restraint (basal; $n=23$ wild-type, $22 \mathrm{PKC} \varepsilon$ null), after 10 minutes of restraint ( $n=11$ of each genotype), or 1 hour after restraint ( $n=6$ of each genotype). Two-factor ANOVA showed significant effects of genotype $\left(F_{1,73}=24.03 ; P<0.001\right)$ and treatment $\left(\mathrm{F}_{2,73}=33.44 ; P<0.001\right)$. ${ }^{*} P<0.05$ compared with wildtype levels for each treatment and $+P<0.05$ compared with basal levels in same genotype (Tukey's test). (b) Basal ACTH levels were elevated in hybrid male wild-type mice $(n=16)$ compared with PKCE-null $(n=13)$ mice ( $P=0.012$, two-tailed $t$ test). (c) Corticosterone levels in hybrid male mice 30 minutes after intraperitoneal injection $(500 \mu \mathrm{l})$ of saline, $10 \mu \mathrm{g} / \mathrm{kg}$ CRF, or $100 \mathrm{mg} / \mathrm{kg}$ metyrapone. Two-factor ANOVA showed a significant effect of treatment $\left(F_{2,76}=18.5, P<0.001\right)$ but not genotype, with levels higher after CRF and lower after metyrapone than after saline $(P<0.001$, Newman Keuls test). ${ }^{*} P=0.026$ compared with saline-treated wildtype mice (Newman Keuls test). (d) ACTH levels in hybrid male mice 30 minutes after treatment with saline, CRF, or metyrapone. Twofactor ANOVA revealed an effect of treatment $\left(F_{2,62}=9.81\right.$, $P<0.001)$ but not of genotype with ACTH levels higher after CRF or metyrapone than after saline $(P<0.05$, Newman Keuls test $)$.

arms compared with wild-type littermates (Figure 2a). There was no difference in the number of entries into the closed arms, confirming that overall locomotor activity was similar in both genotypes. Similar genotype-specific differences in open-arm entries and time spent in the open arms were apparent in inbred 129SvJae mice (Figure 2b).

Reduced stress responses in PKCE-null mice. Since our findings indicated reduced anxiety-like behavior in PKCE-null mice, we postulated that these mice would also show a reduced response to stress. To assess the intensity of response to stressors, we measured plasma levels of the stress hormones corticosterone and ACTH.
Baseline levels of these hormones were lower in PKCEnull mice compared with wild-type mice (Figure 3, a and b). Immediately after a 10-minute period of restraint, corticosterone levels increased in both genotypes, but were still lower in PKCE-null mice (Figure 3a). One hour after restraint, levels remained elevated in wild-type mice, whereas in PKCE-null mice they were no longer significantly different than baseline.

Decreased levels of stress hormones could result from reduced pituitary response to the hypothalamic hormones arginine vasopressin (AVP) and CRF, which stimulate secretion of $\mathrm{ACTH}$, or from a reduced adrenal response to ACTH. However, CRF evoked similar levels of ACTH and corticosterone in both genotypes (Figure 3, $c$ and d). In addition, adrenal weight was similar $(P=0.43)$ in wild-type $(6.06 \pm 0.57 \mathrm{mg} ; n=15)$ and PKC -null $(6.15 \pm 0.63 \mathrm{mg} ; n=12)$ mice. Since decreased basal levels of corticosterone and ACTH could result from impaired release of CRF and AVP from the paraventricular nucleus of the hypothalamus (PVN), we examined the capacity of the PVN to drive the HPA axis by blocking glucocorticoid-mediated feedback suppression of the PVN with metyrapone, which inhibits adrenal corticosterone synthesis. Metyrapone reduced levels of corticosterone (Figure 3c) and evoked similar elevations in ACTH in PKCE-null and wild-type mice (Figure 3d).

PKCE-null mice show increased sensitivity to neurosteroids. $\mathrm{GABA}_{\mathrm{A}}$ receptors from PKCE-null mice show enhanced sensitivity to the allosteric activators ethanol and flunitrazepam (20). If reduced anxiety-like behavior in PKCE-null mice is related to increased sensitivity of $\mathrm{GABA}_{\mathrm{A}}$ receptors to allosteric activators, then there must be an endogenous activator that is more effective in PKCE-null mice. One candidate is the neurosteroid allopregnanolone, a metabolite of progesterone that allosterically enhances the action of GABA at $\mathrm{GABA}_{\mathrm{A}}$ receptors (26). Treatment of membranes (microsacs) isolated from frontal cortex of mice with allopregnanolone or the related compound pregnanolone enhanced muscimol-stimulated ${ }^{36} \mathrm{Cl}$ uptake in both wild-type and PKCE-null mice, but the effect was greater in PKCE-null mice (Figure 4a). Examination of the concentration-response relationship using a synthetic analogue, alphaxalone, revealed that absence of PKCE was associated with an increase in the maximal effect rather than a change in the $\mathrm{ED}_{50}$ for the neurosteroid (Figure 4a). These in vitro results were associated with enhanced sensitivity to the hypnotic effect of pregnanolone as assessed by the duration of the loss of righting reflex (Figure 4c). They were not associated with a difference in brain allopregnanolone concentration in PKCE-null mice (Figure 4d).

Bicuculline restores wild-type levels of corticosterone and anxiety-like behavior in PKCE-null mice. The HPA axis is regulated by limbic forebrain circuits that stimulate or inhibit release of CRF and AVP from the PVN (27). Inhibitory circuits connect with the PVN through GABA-containing neurons in the bed nucleus of the 

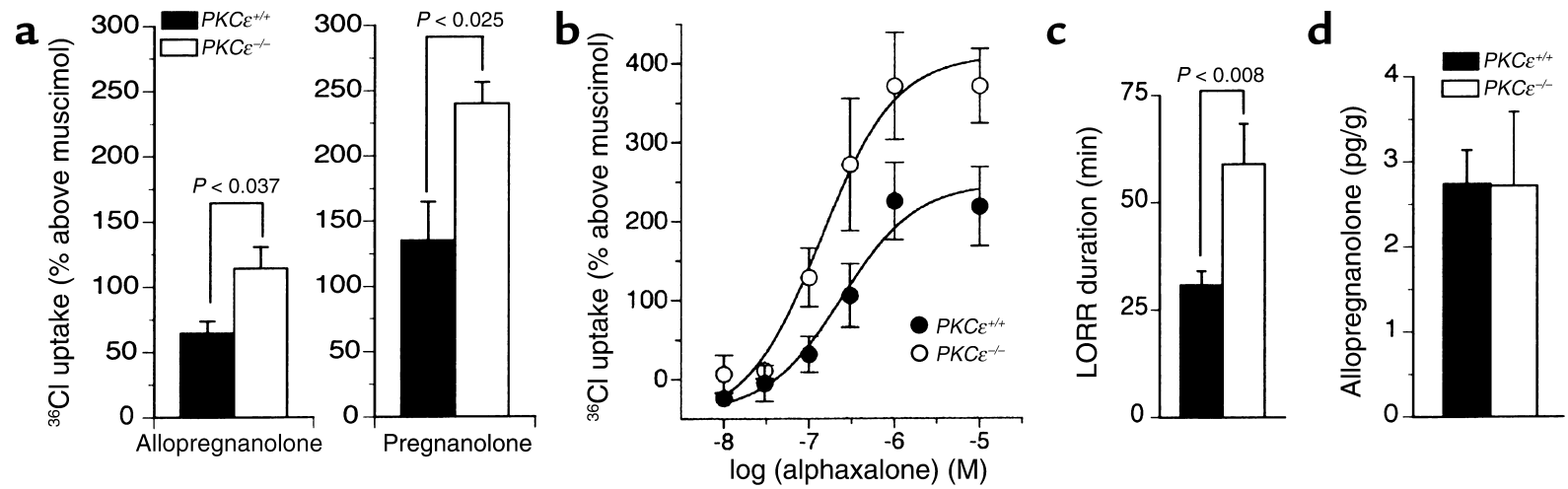

\section{Figure 4}

Responses to neurosteroids in PKCE-null mice. (a) Muscimol-stimulated ${ }^{36} \mathrm{Cl}$ uptake in the presence of $1 \mathrm{nM}$ allopregnanolone $(n=11$ of each genotype) or $1 \mu \mathrm{M}$ pregnanolone ( $n=4$ of each genotype) was greater in tissue from hybrid PKCE-null compared with tissue from hybrid wild-type mice (two-tailed $t$ tests). (b) Microsacs from frontal cortex of hybrid PKCE-null mice (open circles) show greater muscimol-stimulated ${ }^{36} \mathrm{Cl}$ uptake in the presence of alphaxalone compared with microsacs from hybrid wild-type mice (filled circles). Nonlinear regression analysis revealed an increased maximal response to alphaxalone in PKCE-null mice $(409.4 \pm 26.5 \% ; n=4-8)$ compared with wild-type mice $(247.1 \pm 26.9 \%, P=0.005 ; n=4-6)$, without a difference in $\log \mathrm{ED}_{50}$ values $(-6.86 \pm 0.14$ in PKCE-null and $-6.62 \pm 0.20$ in wild-type mice; $P=0.826)$. (c) The duration of the pregnanolone-induced loss of the righting reflex (LORR) was greater $(P=0.008$; two-tailed unpaired $t$ test $)$ in hybrid male PKCE-null mice $(n=9)$ compared with wild-type male littermates $(n=8)$. (d) Total brain levels of alphaxalone were similar in hybrid wild-type $(n=8)$ and PKCE-null $(n=9)$ mice.

stria terminalis, the preoptic area, and the hypothalamus. Stimulation of these neurons inhibits the HPA axis, presumably through activation of $\mathrm{GABA}_{\mathrm{A}}$ receptors present on PVN neurons. Since in previous work we found that $\mathrm{GABA}_{\mathrm{A}}$ receptor responses are enhanced in PKCE-null mice (20), we postulated that the lower levels of corticosterone present following stress in these mice were related to increased GABA-mediated suppression of the HPA axis. To investigate this possibility, we induced stress by injecting mice with saline alone or with saline containing the $\mathrm{GABA}_{\mathrm{A}}$ receptor antagonist bicuculline $(1-2 \mathrm{mg} / \mathrm{kg})$. We chose these concentrations of bicuculline because they are below those reported $(6-8 \mathrm{mg} / \mathrm{kg})$ to increase anxiety-like behavior in wild-type mice (28) and are just below the $\mathrm{ED}_{50}(2.28$ $\mathrm{mg} / \mathrm{kg}$ ) for inducing convulsions in mice (29). Following saline injection, corticosterone levels were higher in wild-type mice compared with PKCe-null mice (Figure $5 a)$. Bicuculline $(1-2 \mathrm{mg} / \mathrm{kg})$ elevated corticosterone in PKC $\varepsilon$-null mice to levels observed in wild-type mice, but as expected had little effect on levels in wild-type mice (Figure 5a). No mice suffered convulsions at these concentrations of bicuculline.

If the reduction in corticosterone levels in PKCE-null mice is related to neurosteroid hypersensitivity, we predicted that injection of allopregnanolone would reduce
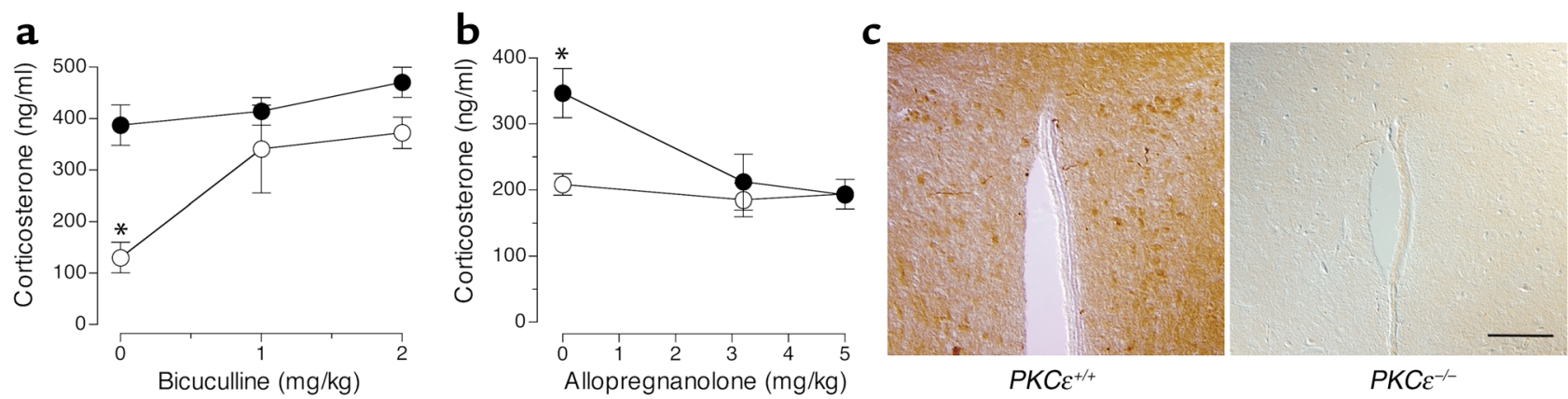

Figure 5

$\mathrm{GABA}_{A}$ receptor regulation of corticosterone in PKCE-null mice. (a) Corticosterone levels measured 30 minutes after injection of saline or bicuculline in hybrid male PKC $\varepsilon$-null (open circles; $n=3-7$ ) and wild-type mice (filled circles; $n=4-6$ ). Two-way ANOVA revealed an effect of genotype $\left(F_{1,25}=16.11, P<0.001\right)$ and concentration $\left(F_{2,25}=7.32, P=0.003\right)$ and a significant interaction between these factors $\left(F_{2,25}=3.979\right.$, $P=0.032)$. ${ }^{*} P<0.05$ compared with saline-treated wild-type mice and with bicuculline-treated PKCE-null mice (Tukey's test). (b) Corticosterone levels in hybrid male PKCE-null (open circles; $n=6-12$ ) and wild-type mice (filled circles; $n=6-10$ ) after intraperitoneal injection of saline or allopregnanolone followed by 10 minutes of restraint. Two-way ANOVA revealed an effect of genotype $\left(F_{1,41}=4.96, P=0.032\right)$ and concentration $\left(\mathrm{F}_{2,41}=5.85, P=0.006\right)$ and a significant interaction between these two factors $\left(\mathrm{F}_{2,41}=3.53, P=0.039\right)$. ${ }^{*} P<0.05$ compared with saline-treated PKCE-null mice and allopregnanolone-treated wild-type mice (Tukey's test). (c) PKCE-like immunoreactivity in the PVN of wild-type $\left(P K C \varepsilon^{+/+}\right)$and PKCE-null $\left(P K C \varepsilon^{-/-}\right)$mice. Bar, $100 \mu \mathrm{m}$. 

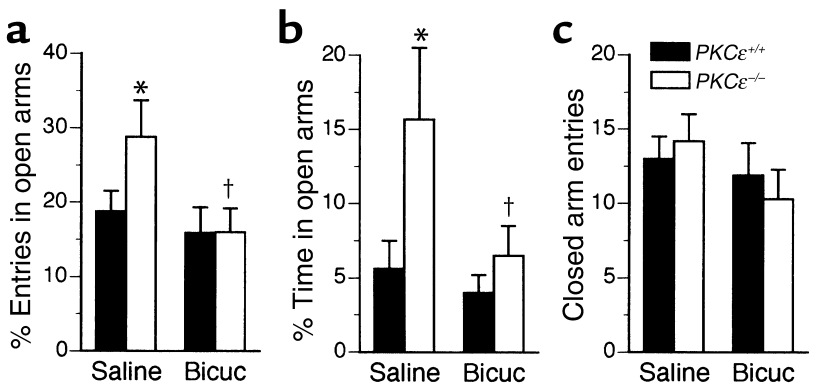

\section{Figure 6}

Bicuculline increases anxiety-like behavior in PKCE-null mice. Data are from 25 wild-type and 23 PKCE-null mice treated with saline and 20 wild-type and 19 PKC $\varepsilon$-null mice treated with bicuculline. Two-factor ANOVA revealed main effects of treatment $\left(F_{1,84}=4.2, P=0.043\right)$ on the percentage of total entries into the open arms (a) and genotype $\left(F_{1,84}=4.4, P=0.039\right)$ on the percentage of time spent in the open arms (b). There were no significant effects of either factor on the number of closed-arm entries (c). ${ }^{*} P<0.05$ compared with salinetreated wild-type mice, and $P<0.05$ compared with saline-treated PKCE-null mice (Tukey's test).

corticosterone levels, but this effect would be diminished in PKCE-null mice since their $\mathrm{GABA}_{\mathrm{A}}$ receptors would already be more activated by endogenous allopregnanolone than receptors in wild-type mice. We found that $3-5 \mathrm{mg} / \mathrm{kg}$ allopregnanolone administered before restraint stress reduced plasma corticosterone in wild-type mice, whereas in PKCE-null mice it had no effect (Figure $5 b$ ). In vitro, allopregnanolone suppresses CRF release from hypothalamic explants (30). Therefore, we investigated whether PKCE is expressed in the mouse PVN. Immunohistochemical analysis revealed PKCE-like immunoreactivity in the PVN of wild-type but not of PKCE-null mice (Figure 5c), consistent with a role for PKC $\varepsilon$ in regulating neurosteroid sensitivity of the HPA axis at the level of the hypothalamus.

If decreased anxiety-like behavior in PKCE-null mice also results from enhanced activity of $\mathrm{GABA}_{\mathrm{A}}$ receptors, then we predicted that treatment with a $\mathrm{GABA}_{\mathrm{A}}$ receptor antagonist would be anxiogenic in these mice at a concentration that would have little effect on anxiety-related behavior in wild-type mice. Using the elevated plus maze, we found that pretreatment with $1.5 \mathrm{mg} / \mathrm{kg}$ of bicuculline 20 minutes before testing decreased the percentage of time spent in the open arms and the percentage of open-arm entries in PKC $\varepsilon$ null mice, but not in wild-type mice (Figure 6, a and b). The number of closed-arm entries was not altered by bicuculline (Figure 6c).

\section{Discussion}

In this study we found that absence of PKC $\varepsilon$ is associated with reduced anxiety-like behaviors and decreased levels of stress hormones in mice. Reduced anxiety-like behavior was present in hybrid as well as inbred PKCEnull mice, indicating that despite differences in genetic background, we could still detect an effect of the PKCEnull mutation. This was associated with increased sen- sitivity of $\mathrm{GABA}_{A}$ receptors to neurosteroids. Furthermore, treatment with the $\mathrm{GABA}_{\mathrm{A}}$ receptor antagonist bicuculline restored levels of stress hormones and anxiety-like behavior in PKCE-null mice to wild-type levels. These results suggest that increased $\mathrm{GABA}_{\mathrm{A}}$ receptor sensitivity to endogenous positive neurosteroid modulators contributes to reduced anxiety-like behavior and stress hormone responses in PKCE-null mice. These findings also suggest that inhibitors of PKCE might prove useful as anxiolytic drugs.

Although primary pituitary or adrenal insufficiency reduces ACTH and corticosterone levels, our results indicate that neither accounts for reduced levels of stress hormones in PKCE-null mice. For example, we found that restraint increased corticosterone levels threefold in wild-type and sixfold in PKCE-null mice. One hour later, levels still appeared elevated about 2.2-fold in both genotypes, although this was not statistically significant in PKC $\varepsilon$-null mice. This suggests that HPA axis function is intact but is consistently downregulated across basal and stress-related conditions in PKCE-null mice. This is supported by the findings that exogenous CRF evoked similar levels of ACTH and corticosterone in wild-type and PKC $\varepsilon$-null mice and that adrenal weight was similar in both genotypes. That corticosterone levels were different after saline injection despite similar levels of ACTH is consistent with secondary adrenal insufficiency in PKC $\varepsilon$-null mice due to decreased basal stimulation of the HPA axis. Reduced levels of stress hormones in PKCE-null mice are also not due to impaired PVN function because treatment with metyrapone to remove glucocorticoid-mediated feedback inhibition of the PVN evoked similar elevated levels of ACTH and corticosterone in wild-type and PKCE-null littermates. Taken together, these findings indicate that a primary defect in HPA axis function does not account for reduced basal and stress-induced levels of corticosterone in PKCE-null mice.

Reduced levels of stress hormones in these mice could also result from suppression of the HPA axis through enhanced activation of $\mathrm{GABA}_{\mathrm{A}}$ receptors on PVN neurons by GABA released from neurons projecting to the hypothalamus from other brain regions (27). In support of this mechanism, we found that treatment with bicuculline restored wild-type levels of corticosterone and anxiety-like behavior in PKCE-null mice, suggesting that reduced levels of stress hormones and anxiety-like behavior in these mice are consequences of enhanced $\mathrm{GABA}_{\mathrm{A}}$ receptor activity. The fact that allopregnanolone lowered corticosterone levels in wild-type mice, but not in PKCE-null mice, strongly suggests that enhanced neurosteroid activation of $\mathrm{GABA}_{A}$ receptors is a major factor reducing stress hormone levels in PKCE-null mice.

One limitation of our studies is that they were conducted using conventional knockout mice, so it is possible that the phenotypes observed are due to a developmental change rather than absence of PKC $\varepsilon$ in adulthood. 
However, we demonstrated previously that exposing $\mathrm{GABA}_{\mathrm{A}}$ receptors from wild-type mice to the selective PKC $\varepsilon$ inhibitor peptide, $\varepsilon V 1-2$, produces allosteric supersensitivity (20). This indicates that increased $\mathrm{GABA}_{\mathrm{A}}$ receptor sensitivity to allosteric modulators in PKCE-null mice results from absence of PKC $\varepsilon$ function in adult neurons and is not likely a consequence of altered nervous system development. Since our findings here demonstrate that enhanced $\mathrm{GABA}_{\mathrm{A}}$ receptor function is critical for reduced anxiety-like behavior and stress hormone responses in PKCE-null mice, we think it is likely that these phenotypes also result from absence of PKC $\varepsilon$ function in the adult brain, rather than from altered development. However, proof of this will require studies in which PKCE is eliminated or restored by an inducible system in adult mice.

Our finding that absence of PKCE increases the maximal response to alphaxalone suggests that $\mathrm{PKC} \varepsilon$ regulates the number of neurosteroid-binding sites available on $\mathrm{GABA}_{\mathrm{A}}$ receptors or increases the coupling of sites to modulation of channel function. We think it more likely to involve coupling of allosteric sites rather than an increase in receptor density because absence of PKC $\varepsilon$ does not affect behavioral or biochemical responses to direct agonists or alter the binding of the benzodiazepine antagonist Ro 15-1788 to brain membranes (20). It is also unlikely to involve a change in receptor subunit composition because we found previously that treating microsacs from wild-type mice for 15 minutes with a PKCE inhibitor was sufficient to enhance the $\mathrm{GABA}_{\mathrm{A}}$ receptor response to flunitrazepam (20). In addition, transgenic expression of a fragment of PKCE that inhibits its function (31) also enhanced the $G_{A B A}$ receptor response to benzodiazepines in cells that express only $\alpha 1, \beta 1$, and $\gamma 2$ subunits (T. McMahon and R. Messing, unpublished observations).

PKC has been implicated in regulating the response of $\mathrm{GABA}_{\mathrm{A}}$ receptors to direct agonists. Phorbol esters $(32,33)$ or an active catalytic fragment of PKC (PKM) (34) alter receptor activation by GABA or muscimol, and functional studies using site-directed mutagenesis have determined that this modulation is mediated by phosphorylation of specific serine residues on $\beta 1, \beta 2$, and, $\gamma 2$ subunits (32-34). It is unlikely that these sites are involved in the effect of PKCE because we found that activation of $\mathrm{GABA}_{\mathrm{A}}$ receptors by the direct agonist muscimol was similar in tissue from wild-type and PKCE-null mice (20). PKCE may phosphorylate other sites on $\mathrm{GABA}_{\mathrm{A}}$ receptor subunits or another protein that modulates receptor responses to allosteric activators. Identification of the PKCE substrates involved should provide clues to the mechanism by which PKCE regulates $\mathrm{GABA}_{\mathrm{A}}$ receptor function.

Absence of another PKC isozyme, $\mathrm{PKC} \gamma$, is associated with reduced anxiety-like behavior in mice (11). However, absence of PKC $\gamma$ is not likely to reduce anxiety through an effect on $\mathrm{GABA}_{\mathrm{A}}$ receptors because loss of $P K C \gamma$ selectively reduces $G A B A_{A}$ receptor responses to ethanol but does not affect responses to direct agonists or other allosteric drugs (35). PKC $\gamma$ has been proposed instead to modulate anxiety through serotonergic pathways (11). Further work is needed to determine whether PKCE also modulates serotonergic systems that control anxiety and hormonal responses to stress.

\section{Acknowledgments}

We thank S. Taylor and J. Connolly for technical support and P. Janak for helpful discussions. This work was supported by funds provided by the State of California for medical research on alcohol and substance abuse through the University of California at San Francisco and by NIH grants AA-09981 to C.W. Hodge, AG20079 to J. Raber, and AA-08117 to R.O. Messing.

1. Kessler, R.C., et al. 1994. Lifetime and 12-month prevalence of DSM-III-R psychiatric disorders in the United States. Results from the National Comorbidity Survey. Arch. Gen. Psychiatry. 51:8-19.

2. Deckert, J., et al. 1999. Excess of high activity monoamine oxidase A gene promoter alleles in female patients with panic disorder. Hum. Mol. Genet. 8:621-624.

3. Deckert, J., et al. 1998. Systematic mutation screening and association study of the $\mathrm{A} 1$ and $\mathrm{A} 2 \mathrm{a}$ adenosine receptor genes in panic disorder suggest a contribution of the A2a gene to the development of disease. Mol. Psychiatry. 3:81-85.

4. Kennedy, J.L., et al. 1999. Investigation of cholecystokinin system genes in panic disorder. Mol. Psychiatry. 4:284-285.

5. Wang, Z., Valdes, J., Noyes, R., Zoega, T., and Crowe, R.R. 1998. Possible association of a cholecystokinin promotor polymorphism (CCK-36CT) with panic disorder. Am. J. Med. Genet. 81:228-234.

6. Turri, M.G., Datta, S.R., DeFries, J., Henderson, N.D., and Flint, J. 2001. QTL analysis identifies multiple behavioral dimensions in ethological tests of anxiety in laboratory mice. Curr. Biol. 11:725-734.

7. Smith, G.W., et al. 1998. Corticotropin releasing factor receptor 1-deficient mice display decreased anxiety, impaired stress response, and aberrant neuroendocrine development. Neuron. 20:1093-1102.

8. Timpl, P., et al. 1998. Impaired stress response and reduced anxiety in mice lacking a functional corticotropin-releasing hormone receptor 1. Nat. Genet. 19:162-166.

9. Tronche, F., et al. 1999. Disruption of the glucocorticoid receptor gene in the nervous system results in reduced anxiety. Nat. Genet. 23:99-103.

10. Chen, C., Rainnie, D.G., Greene, R.W., and Tonegawa, S. 1994. Abnormal fear response and aggressive behavior in mutant mice deficient for alpha-calcium-calmodulin kinase II. Science. 266:291-294.

11. Bowers, B.J., Collins, A.C., Tritto, T., and Wehner, J.M. 2000. Mice lacking PKC gamma exhibit decreased anxiety. Behav. Genet. 30:111-121.

12. Kash, S.F., Tecott, L.H., Hodge, C., and Baekkeskov, S. 1999. Increased anxiety and altered responses to anxiolytics in mice deficient in the 65$\mathrm{kDa}$ isoform of glutamic acid decarboxylase. Proc. Natl. Acad. Sci. USA. 96:1698-1703.

13. Crestani, F., et al. 1999. Decreased GABAA-receptor clustering results in enhanced anxiety and a bias for threat cues. Nat. Neurosci. 2:833-839.

14. Bale, T.L., et al. 2000. Mice deficient for corticotropin-releasing hormone receptor-2 display anxiety-like behaviour and are hypersensitive to stress. Nat. Genet. 24:410-414.

15. Kishimoto, T., et al. 2000. Deletion of crhr2 reveals an anxiolytic role for corticotropin-releasing hormone receptor-2. Nat. Genet. 24:415-419.

16. Heisler, L.K., et al. 1998. Elevated anxiety and antidepressant-like responses in serotonin 5-HT1A receptor mutant mice. Proc. Natl. Acad. Sci. USA. 95:15049-15054.

17. Parks, C.L., Robinson, P.S., Sibille, E., Shenk, T., and Toth, M. 1998. Increased anxiety of mice lacking the serotonin1A receptor. Proc. Natl. Acad. Sci. USA. 95:10734-10739.

18. Ramboz, S., et al. 1998. Serotonin receptor 1A knockout: an animal model of anxiety-related disorder. Proc. Natl. Acad. Sci. USA. 95:14476-14481.

19. Salzman, C., Miyawaki, E.K., le Bars, P., and Kerrihard, T.N. 1993. Neurobiologic basis of anxiety and its treatment. Harv. Rev. Psychiatry. 1:197-206.

20. Hodge, C.W., et al. 1999. Supersensitivity to allosteric $\mathrm{GABA}_{\mathrm{A}}$ receptor modulators and alcohol in mice lacking PKCE. Nat. Neurosci. 2:997-1002.

21. Khasar, S.G., et al. 1999. A novel nociceptor signaling pathway revealed in protein kinase C $\varepsilon$ mutant mice. Neuron. 24:253-260.

22. Olive, M.F., Mehmert, K.K., Messing, R.O., and Hodge, C.W. 2000. Reduced operant ethanol self-administration and in vivo mesolimbic 
dopamine responses to ethanol in PKCE-deficient mice. Eur. J. Neurosci. 12:4131-4140

23. VanDoren, M.J., et al. 2000. Neuroactive steroid 3alpha-hydroxy-5alphapregnan-20-one modulates electrophysiological and behavioral actions of ethanol. J. Neurosci. 20:1982-1989.

24. Kiley, S.C., and Parker, P.J. 1995. Differential localization of protein kinase $\mathrm{C}$ isozymes in $\mathrm{U} 937$ cells: evidence for distinct isozyme functions during monocyte differentiation. J. Cell Sci. 108:1003-1016.

25. Crawley, J.N. 2000. What's wrong with my mouse? Wiley-Liss. New York, New York, USA. 329 pp.

26. Paul, S.M., and Purdy, R.H. 1992. Neuroactive steroids. FASEB J. 6:2311-2322.

27. Herman, J.P., and Cullinan, W.E. 1997. Neurocircuitry of stress: central control of the hypothalamo-pituitary-adrenocortical axis. Trends Neurosci. 20:78-84

28. Dalvi, A., and Rodgers, R.J. 1996. GABAergic influences on plus-maze behaviour in mice. Psychopharmacology (Berl). 128:380-397.

29. Yajima, Y., et al. 2000. Effects of differential modulation of mu-, deltaand kappa-opioid systems on bicuculline-induced convulsions in the mouse. Brain Res. 862:120-126.

30. Patchev, V.K., Shoaib, M., Holsboer, F., and Almeida, O.F.X. 1994. The neurosteroid tetrahydroprogesterone counteracts corticotropin-releasing hormone-induced anxiety and alters the release and gene expression of corticotropin-releasing hormone in the rat hypothalamus. Neuroscience. 62:265-271.

31. Hundle, B., et al. 1997. An inhibitory fragment derived from protein kinase $\mathrm{C} \varepsilon$ prevents enhancement of nerve growth factor responses by ethanol and phorbol esters. J. Biol. Chem. 272:15028-15035.

32. Kellenberger, S., Malherbe, P., and Sigel, E. 1992. Function of the $\alpha 1 \beta 2 \gamma 2 \mathrm{~S} \gamma$-aminobutyric acid type A receptor is modulated by protein kinase $\mathrm{C}$ via multiple phosphorylation sites. J. Biol. Chem. 267:25660-25663.

33. Krishek, B.J., et al. 1994. Regulation of $\mathrm{GABA}_{\mathrm{A}}$ receptor function by protein kinase C phosphorylation. Neuron. 12:1081-1095.

34. Lin, Y.F, et al. 1996. Enhancement of recombinant alpha 1 beta 1 gamma $2 \mathrm{~L}$ gamma-aminobutyric acid A receptor whole-cell currents by protein kinase $\mathrm{C}$ is mediated through phosphorylation of both beta 1 and gamma 2L subunits. Mol. Pharmacol. 50:185-195.

35. Harris, R.A., McQuilkin, S.J., Paylor, R., Tonegawa, S., and Wehner, J.M. 1995. Mutant mice lacking the $\gamma$ isoform of protein kinase $C$ show decreased behavioral actions of ethanol and altered function of $\gamma$-aminobutyrate type A receptors. Proc. Natl. Acad. Sci. USA. 92:3658-3662. 